\title{
HUBUNGAN PERSEPSI TENTANG KAWASAN TANPA ROKOK (KTR) DENGAN PERILAKU MEROKOK PEGAWAI DI DINAS KESEHATAN KOTA TEBING TINGGI
}

\author{
Khairatunnisa $^{1}$, Indra Fachrizal ${ }^{2}$ \\ ${ }^{1,2}$ Fakultas Kesehatan Masyarakat, Institut Kesehatan Helvetia Medan \\ e-mail: khairatunnisa@helvetia.ac.id ${ }^{1}$; indrafachrizal85@gmail.com²
}

\begin{abstract}
Smoking behavior is a problem related to public health. The results of the preliminary survey show that the Health Department of Tebing Tinggi has implemented Non-Smoking Area, but in reality there are still employees who smoke in the area of Tebing Tinggi City Health Department. The purpose of this study was to determine the relationship of perceptions about non-smoking area with smoking behavior of employees at the Health Department of Tebing Tinggi City. Research method: this type of research is survey explanatory research with a cross sectional approach. The population of this study was 45 employees in the Health Department of Tebing Tinggi, with the sample being the entire population. Data analysis used univariate and bivariate analysis with fisher exact test. Results: the results showed that most employees' perceptions of Non-Smoking Area were sufficient (60\%) and most employees were smoking (75.6\%). The results of the statistical test showed that there was a relationship between perceptions of Non-Smoking Area and the smoking behavior of employees at the Tebing Tinggi City Health Department in 2018 with a value of $p=0.001$. Suggestion: it is suggested to the Government of Tebing Tinggi to review the implementation of the existing Regulations and add supervision content so that the implementation of Non-Smoking Area can run well and the Head of the Health Department of Tebing Tinggi City to form a task force to monitor the implementation of Non-Smoking Area.
\end{abstract}

Keywords: Perception, Smoking Behavior, Non-Smoking Area

\section{PENDAHULUAN}

Perilaku merokok merupakan masalah yang berkaitan dengan kesehatan masyarakat karena dapat menimbulkan berbagai penyakit bahkan dapat menyebabkan kematian baik bagi perokok dan orang yang ada disekitarnya (perokok pasif). Setiap orang telah mengetahui bahwa merokok adalah berbahaya bagi kesehatan, namun pada kenyataannya perilaku merokok masih sangat sulit dikendalikan. Merokok juga dapat menjadi awal bagi seseorang lebih mudah untuk mencoba berbagai zat adiktif yang lain tersebut dari pada bukan seorang perokok (Kementerian Kesehatan RI, 2016).

Rokok merupakan salah satu masalah publik yang mengemuka di masyarakat. Bagi perokok aktif tentu paparan asap rokok sama sekali tidak menjadi masalah dalam kehidupannya. 
Namun asap rokok sangat merugikan kesehatan perokok pasif seperti menyebabkan berbagai penyakit (kanker paru, penyakit jantung, asma) dan mengganggu masyarakat lainnya yang ingin menjalankan kehidupan dengan pola hidup sehat.

Data World Health Organization (WHO) tahun 2017 menunjukkan bahwa Indonesia menduduki peringkat ketiga dengan jumlah perokok terbesar di dunia setelah Cina dan India. Jumlah perokok di Indonesia mencapai $35 \%$ dari total populasi, atau sekitar 75 juta jiwa. Belum lagi pertumbuhan prevalensi perokok pada anak-anak dan remaja yang tercepat di dunia sebesar $19.4 \%$.

Menurut hasil Riset Kesehatan Dasar (Riskesdas) tahun 2013, perilaku merokok menurut kelompok umur dan kebiasaan merokok sebesar 0,5\% perokok umur 10-14 tahun merokok setiap hari dan $0,9 \%$ perokok kadangkadang. Pada kelompok umur 15-19 tahun sebesar $11,2 \%$ perokok setiap hari dan $7,1 \%$ perokok kadang-kadang, sedangkan pada kelompok umur 20-24 tahun sebesar $27,2 \%$ perokok setiap hari dan $6,9 \%$ perokok kadang-kadang. Proporsi terbanyak perokok aktif setiap hari pada umur 30-34 tahun sebesar $33,4 \%$ dan umur 35-39 tahun sebesar
$32,2 \%$ yang merupakan penduduk usia produktif (Riskesdas, 2013).

Kebijakan pengendalian tembakau di Indonesia masih menimbulkan perdebatan yang panjang, mulai dari hak azasi seorang perokok, fatwa haram merokok di tempat umum sampai dampak anti rokok terhadap perekonomian dan tenaga kerja di Indonesia. Padahal hasil kajian di beberapa negara telah menunjukkan bahwa kebijakan merupakan cara yang efektif dalam mengendalikan tembakau atau lebih khusus dalam mengurangi kebiasaan merokok. Dalam rangka melindungi individu, masyarakat dan lingkungan terhadap paparan asap rokok, pemerintah telah menetapkan kebijakan kawasan tanpa rokok untuk melindungi seluruh masyarakat dari bahaya asap rokok melalui Undang-Undang No.36 tahun 2009 tentang Kesehatan pada pasal 115 ayat 1 dan 2 yang mengamanatkan kepada Pemerintah Daerah wajib untuk menetapkan dan menerapkan kawasan tanpa rokok di wilayahnya (Kementerian Kesehatan RI, 2015).

Provinsi Sumatera Utara juga telah mengeluarkan Peraturan Daerah Nomor 3 Tahun 2014 tentang Kawasan Tanpa Rokok. Semua fasilitas pelayanan kesehatan, tempat proses belajar 
mengajar, tempat bermain anak, tempat ibadah, angkutan umum, tempat kerja, dan tempat umum, sudah ditetapkan sebagai kawasan tanpa asap rokok. Namun sampai tahun 2017, implementasinya belum terlihat. Total, dari 33 kabupaten dan kota, baru lima kabupaten dan kotalah yang mempunyai peraturan KTR yaitu Kabupaten Serdang Bedagai, Kota Pematang Siantar, Kota Tebing Tinggi, Kota Medan dan Kabupaten Asahan (Medan, 2014) .

Dibentuknya Peraturan Walikota Tebing Tinggi No.3 Tahun 2013 tentang kawasan tanpa rokok dan kawasan terbatas merokok merupakan landasan hukum untuk setiap orang atau badan guna mendapatkan hak yang sama untuk kawasan tanpa rokok yang sehat, dan setiap orang atau badan melaksanakan kewajiban untuk memelihara, dan menjalankan peraturan yang telah dibuat guna menjaga kelestarian lingkungan hidup. Peraturan ini merupakan langkah untuk melindungi masyarakat dari ancaman perokok aktif sehingga budaya dan kebiasaan masyarakat tersebut dalam hal ini kebiasaan merokok memengaruhi terciptanya aturan tentang larangan merokok di tempat umum dengan dibuatnya kawasan tanpa rokok.
Perilaku merokok muncul karena faktor internal juga faktor eksternal. Salah satu faktor internal adalah persepsi. Persepsi yang ditimbulkan berbeda pada tiap orang tentang merokok. Setelah seseorang memiliki persepsi tersendiri tentang merokok kemudian muncul suatu sikap, yaitu kecenderungan seseorang untuk menerima atau menolak, setuju atau tidak setuju terhadap respon yang datang dari luar, dalam hal ini adalah merokok. Jika setuju maka seseorang akan melakukan aktivitas merokok, tapi jika tidak setuju maka seseorang tidak akan merokok (Hidayati, 2012).

Perilaku merokok menurut Laevy dalam Nasution, adalah sesuatu yang dilakukan seseorang berupa membakar dan menghisapnya serta dapat menimbulkan asap yang dapat terisap oleh orang-orang sekitarnya. Sedangkan menurut Aritonang dalam Sulistyo, merokok adalah perilaku yang kompleks, karena merupakan hasil interaksi dari aspek kognitif, kondisi psikologis, dan keadaan fisiologis (Aritonang, 2007; Nasution, 2008).

Perilaku merokok, pada umumnya dilakukan dengan berbagai alasan menurut persepsi perokok, seperti untuk menghilangkan stres, agar terlihat 
jantan, atau iseng saja, alasan lain agar terlihat keren, dapat menimbulkan perasaan relaks, menjadi lebih terkenal dan terlihat muda. Dengan diketahuinya persepsi-persepsi tersebut, akan diketahui faktor-faktor yang dapat memengaruhi perilaku seseorang, termasuk perilaku masyarakat dalam upaya menginisiasi kawasan tanpa rokok.

Penelitian yang dilakukan oleh Khairi tentang persepsi jajaran pimpinan tentang Kawasan Tanpa Rokok (KTR) di Dinas Kesehatan Kabupaten Langkat Tahun 2014 menunjukkan bahwa informan setuju bila di Dinas Kesehatan Kabupaten Langkat dijadikan Kawasan Tanpa Rokok. Semua informan memiliki komitmen yang kuat untuk merealisasikan kawasan tanpa rokok sebagai upaya peningkatan kesehatan dan menjadikan kebijakan kawasan tanpa rokok yang terencana secara baik (Khairi, 2014).

Hasil penelitian Septia tentang hubungan antara persepsi remaja dengan perilaku merokok pada siswa SMA di Bandar Lampung menunjukkan bahwa ada hubungan yang bermakna antara persepsi dengan perilaku merokok. Siswa yang memiliki persepsi negatif mempunyai peluang lebih besar untuk berperilaku merokok dibandingkan dengan siswa yang memiliki persepsi positif (Septia, 2014). Hasil penelitian Rahayuningsih tahun 2015 pada siswa SMK X di Kota Semarang menunjukkan bahwa persepsi berpengaruh terhadap perilaku merokok siswa. Semakin tinggi perceived benefit maka semakin tinggi pula responden untuk tidak merokok karena mengetahui manfaat dari tidak merokok (Rahayuningsih, 2015).

Berdasarkan survei pendahuluan yang telah dilakukan peneliti di Dinas Kesehatan Kota Tebing Tinggi, masih ada pegawai yang merokok di tempat yang dilarang merokok. Ini ditandai dengan masih ada orang yang merokok, adanya puntung rokok di halaman Dinas Kesehatan Kota Tebing Tinggi, serta masih terdapat asbak rokok, korek api dan pemantik di ruangan kerja dan di sekitar aula rapat Dinas Kesehatan Kota Tebing Tinggi. Selain itu masih ditemukan penjualan rokok di kantin Dinas Kesehatan Kota Tebing Tinggi walaupun terdapat tanda larangan merokok (Pemko Tebing Tinggi, 2013).

Hasil wawancara dengan 10 orang pegawai Dinas Kesehatan Kota Tebing Tinggi,bahwa 8 orang masih merokok di Dinas Kesehatan Kota Tebing. Ketika ditanyakan alasan mereka mengapa 
masih merokok di kawasan KTR sebanyak 4 orang mengatakan tidak bisa konsentrasi dalam bekerja kalau tidak merokok, 2 orang mengatakan bahwa KTR tidak perlu diterapkan dan 2 lagi mengatakan bahwa merokok sudah jadi kebiasaan dan sulit ditinggalkan. Berdasarkan latar belakang tersebut maka peneliti tertarik untuk melakukan penelitian yang berjudul "Hubungan Persepsi tentang Kawasan Tanpa Rokok dengan Perilaku Merokok Pegawai di Dinas Kesehatan Kota Tebing Tinggi”.

\section{METODE PENELITIAN}

Jenis penelitian ini berupa Survei explanatory research yang bersifat analitik dengan pendekatan Cross Sectional yaitu penelitian yang dilakukan dengan cara pendekatan, observasi atau pengumpulan data sekaligus pada suatu saat (pada saat bersamaan) (Hidayat, 2014). Populasi penelitian ini adalah seluruh pegawai laki-laki yang ada di Dinas Kesehatan Kota Tebing Tinggi baik PNS maupun honorer sebanyak 45 orang. Oleh karena populasi penelitian ini relatif kecil maka semua populasi penelitian ini diambil sebagai sampel yaitu sebanyak 45 orang. Analisis data yang digunakan yaitu analisis univariat dan analisis bivariat dengan statistik uji fisher exact test pada tingkat kepercayaan $95 \%$.

\section{HASIL PENELITIAN}

\section{Analisis Univariat}

Hasil penelitian menunjukkan bahwa dari 45 responden, yang memiliki persepsi yang cukup sebanyak 27 orang $(60,0 \%)$, memiliki persepsi yang kurang sebanyak 10 orang $(22,2 \%)$ dan memiliki persepsi yang baik sebanyak 8 orang $(17,8 \%)$. Selanjutnya dari 45 responden, yang merokok sebanyak 34 orang $(75,6 \%)$ dan tidak merokok sebanyak 11 orang $(24,4 \%)$.

Hasil penelitian menunjukkan bahwa sebagian besar responden memiliki persepsi yang cukup. Berdasarkan kuesioner yang dijawab oleh responden terlihat sebagian responden sangat setuju bahwa setiap orang akan memperoleh dampak dari merokok, karena itu KTR adalah upaya perlindungan bagi yang tidak merokok. sebagian besar tidak setuju bahwa sebagai pegawai di Dinas Kesehatan, wajib untuk menerapkan KTR. Mereka sangat setuju jika ada yang merokok di area KTR maka wajib dikenakan denda ataupun sanksi. Mereka juga sangat setuju bahwa kondisi kesehatan para perokok pasif akan menjadi buruk 
karena banyak pegawai yang tidak patuh dengan penerapan KTR.

Tabel 1 Distribusi Persepsi tentang KTR dan Perilaku Merokok Pegawai di Dinas Kesehatan Kota Tebing Tinggi Tahun 2018

\begin{tabular}{lcc}
\hline \multicolumn{1}{c}{ Variabel } & f & $\begin{array}{c}\text { Persentase } \\
(\mathbf{\%})\end{array}$ \\
\hline Persepsi: & 8 & 17,8 \\
Baik & 27 & 60,0 \\
Cukup & 10 & 22,2 \\
Kurang & & \\
\hline Perilaku & & \\
Merokok: & & 75,6 \\
Merokok & 34 & 24,4 \\
Tidak Merokok & 11 & $\mathbf{1 0 0 , 0}$ \\
\hline Jumlah & $\mathbf{4 5}$ & \\
\hline
\end{tabular}

Analisis Bivariat

Hasil analisis bivariat menunjukkan bahwa responden yang memiliki persepsi yang baik dan tidak merokok sebanyak 6 responden $(13,3 \%)$, responden yang memiliki persepsi yang baik dan merokok sebanyak 2 responden $(4,4 \%)$. Selanjutnya, responden yang memiliki persepsi kurang dan tidak merokok sebanyak 3 responden $(6,7 \%)$, responden yang memiliki persepsi cukup dan merokok sebanyak 24 responden $(53,3 \%)$. Sementara itu, responden yang memiliki persepsi kurang dan tidak merokok sebanyak 2 responden $(4,4 \%)$, responden yang memiliki persepsi kurang dan tidak merokok sebanyak 2 responden $(4,4 \%)$ dan responden yang memiliki persepsi kurang dan merokok sebanyak 8 responden $(17,8 \%)$. Hasil uji statistik fisher exact test menunjukkan ada hubungan antara persepsi tentang KTR dengan perilaku merokok pegawai di Dinas Kesehatan Kota Tebing Tinggi Tahun 2018.

Tabel 2 Tabulasi Silang Antara Persepsi tentang KTR dengan Perilaku Merokok Pegawai di Dinas Kesehatan Kota Tebing Tinggi Tahun 2018

\begin{tabular}{|c|c|c|c|c|c|c|c|}
\hline \multirow{3}{*}{ Persepsi } & \multicolumn{4}{|c|}{ Perilaku Merokok } & \multirow{2}{*}{\multicolumn{2}{|c|}{ Jumlah }} & \multirow{3}{*}{$\mathbf{p}$} \\
\hline & \multicolumn{2}{|c|}{ Tidak Merokok } & \multicolumn{2}{|c|}{ Merokok } & & & \\
\hline & $\mathbf{f}$ & $\%$ & $\mathbf{f}$ & $\%$ & $\mathbf{f}$ & $\%$ & \\
\hline Baik & 6 & 13,3 & 2 & 4,4 & 8 & 17,8 & \\
\hline Cukup & 3 & 6,7 & 24 & 53,3 & 27 & 60,0 & 0,001 \\
\hline Kurang & 2 & 4,4 & 8 & 17,8 & 10 & 22,2 & \\
\hline Jumlah & 11 & 24,4 & 34 & 75,6 & 45 & 100,0 & \\
\hline
\end{tabular}

\section{PEMBAHASAN}

Hasil penelitian menunjukkan bahwa sebagian besar responden memiliki persepsi yang cukup. Berdasarkan kuesioner yang dijawab oleh responden terlihat sebagian 
responden sangat setuju bahwa setiap orang akan memperoleh dampak dari merokok, karena itu KTR adalah upaya perlindungan bagi yang tidak merokok. sebagian besar tidak setuju bahwa sebagai pegawai di Dinas Kesehatan, wajib untuk menerapkan KTR. Mereka sangat setuju jika ada yang merokok di area KTR maka wajib dikenakan denda ataupun sanksi. Mereka juga sangat setuju bahwa kondisi kesehatan para perokok pasif akan menjadi buruk karena banyak pegawai yang tidak patuh dengan penerapan KTR.

Hasil penelitian ini sejalan dengan Penelitian yang dilakukan oleh Khairi tentang persepsi jajaran pimpinan tentang Kawasan Tanpa Rokok (KTR) di Dinas Kesehatan Kabupaten Langkat Tahun 2014, menunjukkan bahwa informan setuju bila di Dinas Kesehatan Kabupaten Langkat dijadikan Kawasan Tanpa Rokok. Semua informan memiliki komitmen yang kuat untuk merealisasikan kawasan tanpa rokok sebagai upaya peningkatan kesehatan dan menjadikan kebijakan kawasan tanpa rokok yang terencana secara baik. Ada beberapa rancangan kebijakan yang dinyatakan oleh informan untuk kawasan tanpa rokok di Dinas Kesehatan Kabupaten Langkat yaitu berupa aturan tertulis beserta sanksi-sanksinya, diawali dengan himbauan dan lebih bersifat pada penyadaran dengan menggunakan tahapan-tahapan promosi kesehatan (Khairi, 2014).

Pernyataan tentang berbagai penyakit berbahaya akan muncul akibat dari asap rokok, karena itu KTR diharapkan dapat menyadarkan orang yang merokok untuk tidak merokok, banyak dari responden yang menjawab sangat tidak setuju. Namun mereka sangat setuju bahwa rokok dapat mengakibatkan kematian, untuk itu sesama pegawai harus saling mengingatkan untuk tidak merokok di area KTR. Pelanggaran terhadap kawasan KTR perlu benar-benar ditindaklanjuti, banyak dari responden yang menjawab sangat setuju. Namun mereka sangat tidak setuju bahwa semua pegawai dinas kesehatan wajib mematuhi peraturan di area KTR.

KTR dapat mengubah perilaku masyarakat untuk hidup sehat, penerapan KTR akan meningkatkan produktivitas kerja yang optimal dan dengan adanya KTR, angka kesakitan bahkan kematian karena merokok dapat diturunkan. Atas pernyataan tersebut di atas, sebagian besar tidak menyetujuinya. Namun mereka sangat 
setuju bahwa area KTR akan terlihat lebih bersih dan segar karena udara bebas dari asap rokok. Selain itu KTR adalah solusi bagi seseorang untuk menghindar dari asap rokok.

Banyak dari mereka yang menjawab tidak setuju bahwa adanya KTR akan menghambat para perokok untuk merokok sembarangan. KTR sangat baik diterapkan di Dinas Kesehatan, apalagi banyak orang yang juga merokok. Mereka juga tidak setuju bahwa ada banyak pegawai yang merokok, jadi dengan adanya KTR, para pegawai akan akan menghindari diri dari rokok. Para responden sangat setuju bahwa KTR adalah salah satu cara untuk mengurangi dampak buruk dari rokok. Diberlakukannya KTR akan membuat orang untuk berhenti merokok. Dan KTR sudah diberlakukan di Dinas Kesehatan, maka wajib dipatuhi.

Persepsi adalah mengenal dan memilih berbagai obyek sehubungan dengan tindakan yang akan diambil. Persepsi adalah satu proses pengorganisasian dan penginterpretasian terhadap stimulus yang diterima oleh organisme atau individu sehingga menjadi sesuatu yang berarti dan merupakan aktivitas yang terintegrasi dalam diri individu. Persepsi adalah pengalaman yang dihasilkan melalui indra penglihatan, pendengaran, penciuman, dan sebagainya. Setiap orang mempunyai persepsi yang berbeda, meskipun obyeknya sama. Pengalaman pertama yang tidak menyenangkan akan sangat memengaruhi pembentukan persepsi seseorang. Tetapi karena stimulus yang dihadapi oleh manusia senantiasa berubah, maka persepsi pun dapat berubah-ubah sesuai dengan stimulus yang diterima (Notoatmodjo, 2012).

Beberapa karakteristik juga memengaruhi persepsi seseorang yaitu umur, pendidikan dan masa bekerja. Hal ini sesuai dengan teori bahwa faktorfaktor yang memengaruhi persepsi seseorang menurut Kozier adalah variabel demografis meliputi usia, jenis kelamin, ras dan suku bangsa, variabel sosio-psikologi yaitu faktor sosial dan emosional. Tekanan sosial merupakan pengaruh dari teman kelompok dapat memengaruhi seseorang dalam mempersepsikan mengenai suatu hal, variabel struktural meliputi pengetahuan dan cues of action, dapat berupa isyarat internal atau eksternal misalnya perasaan lemah, gejala yang tidak menyenangkan atau anggapan seseorang terhadap 
kondisi orang terdekat yang menderita suatu penyakit (Kozier, Erb, 2008).

Persepsi responden sudah cukup baik, namun adanya persepsi yang sudah cukup baik ini, belum dapat merubah perilaku merokok responden di Dinas Kesehatan Kota Tebing Tinggi. Hal ini dikarenakan para responden sudah menganggap bahwa merokok merupakan kebutuhan dan kebiasaan bagi mereka, walaupun memiliki persepsi yang cukup baik, perilaku merokok mereka tidak dapat diubah menjadi tidak merokok. Seharusnya persepsi yang dimiliki responden dapat membawa dampak yang besar bagi responden itu sendiri.

Hasil penelitian juga menunjukkan bahwa sebagian besar responden adalah perokok. Adapun alasan-alasan responden yang merokok adalah untuk menghindari stres, agar lebih segar dan tidak mengantuk, untuk meningkatkan konsentrasi bekerja. Para responden yang merokok biasanya merokok di rumah, tempat-tempat umum termasuk pula di area bebas rokok. Dalam hal ini responden menyatakan ada yang menegur untuk tidak merokok namun responden tidak membatasi rokok yang dihisap.
Sejalan dengan penelitian yang dilakukan oleh Virly tahun 2013 pada karyawan di industri pupuk Cikampek, menyatakan bahwa perilaku tentang bahaya merokok yang paling banyak adalah perilaku yang kurang baik. Hasil penelitian ini juga sesuai dengan penelitian yang dilakukan oleh Septia tahun 2014 bahwa perilaku siswa yang merokok sebanyak 44 orang $(47,3 \%)$ (Septia, 2014; Virly, 2013).

Perilaku merokok menurut Komasari dapat juga didefinisikan sebagai aktivitas subyek yang berhubungan dengan perilaku merokoknya, yang diukur melalui intensitas merokok, waktu merokok, dan fungsi merokok dalam kehidupan seharihari. Pendapat lain menurut Amstrong dalam Nasution menyatakan merokok adalah menghisap asap tembakau yang dibakar ke dalam tubuh dan menghembuskannya kembali keluar (Komasari, 2000; Nasution, 2008).

Perilaku merokok menurut Nasution adalah suatu aktivitas atau tindakan mengisap gulungan tembakau yang tergulung kertas yang telah terbakar dan menghembuskannya keluar sehingga dapat menimbulkan asap yang dapat terhisap oleh orang-orang disekitarnya serta dapat menimbulkan 
dampak buruk baik bagi perokok itu sendiri maupun orang-orang disekitarnya (Nasution, 2008).

Berdasarkan hasil tabulasi silang persepsi tentang KTR dengan perilaku merokok pegawai didapatkan hasil bahwa ada hubungan persepsi tentang KTR dengan perilaku merokok pegawai di Dinas Kesehatan Kota Tebing Tinggi, dengan nilai probabilitas sebesar 0,001 . Dapat diasumsikan bahwa apabila persepsi responden tentang KTR baik, maka responden tidak akan merokok. Sebaliknya jika persepsi responden cukup atau kurang tentang KTR, maka responden akan merokok.

Sebagian besar persepsi responden menunjukkan persepsi yang cukup, artinya responden belum sepenuhnya mengganggap bahwa pemberlakuan KTR di Dinas Kesehatan Kota merupakan hal yang baik dan bermanfaat bagi dirinya dan orang lain di sekitar. Hanya $17,8 \%$ saja responden yang benar-benar menganggap baik penerapan KTR di Dinas Kesehatan Kota Tebing Tinggi. Persepsi inilah yang pada akhirnya membentuk perilaku merokok responden. Hal ini terbukti dengan ditemukannya sebanyak 75,6\% responden yang merokok di kawasan Dinas Kesehatan Kota Tebing Tinggi.
Penelitian ini sesuai dengan penelitian yang dilakukan oleh Febriani tahun 2014, hasil uji statistik dengan menggunakan uji chi square menunjukkan ada hubungan yang bermakna antara persepsi tentang penerapan KTR dengan perilaku merokok $p=0,0440$. Pengaruh persepsi mahasiswa tehadap kawasan tanpa rokok dan dukungan penerapan di Universitas Sumatera Utara menyatakan bahwa ada pengaruh signifikan antara pesepsi KTR terhadap dukungan penerapan KTR. Hal ini dimungkinkan karena masih terdapat beberapa faktor yang memengaruhi persepsi, diantaranya demografi sosio psikolog, keseriusan dan kerentanan, manfaat dan hambatan serta petunjuk yang dapat mendukung perubahan perilaku individu agar berhenti merokok (Febriani, 2014).

Hasil penelitian ini juga sesuai dengan penelitian Binita tahun 2016, hasil analisis menunjukkan ada hubungan antara persepsi dengan perilaku merokok dengan nilai $\mathrm{p}=0,032$. Sebagian besar responden memiliki persepsi keseriusan yang sedang $77,6 \%$. keseriusan bahwa tindakan berhenti merokok atau tidak merokok dapat mengurangi risiko atau meminimalkan dampak buruk dari perilaku merokok. 
Hal tersebut menunjukkan bahwa semakin tinggi tingkat keseriusan dan kerentanan yang dirasakan maka semakin tinggi pula responden untuk tidak merokok karena mengetahui dampak penyakit akibat merokok (Binita, 2016).

Penelitian ini juga tidak jauh berbeda dengan penelitian yang telah dilakukan oleh Hidayati tahun 2012, hasil analisis menunjukkan ada hubungan yang kuat antara persepsi dengan perilaku merokok siswa, guru dan karyawan dengan nilai $\mathrm{p}=0,000$. Dapat disimpulkan bahwa ada perbedaan persepsi merokok terhadap perilaku merokok pada siswa, guru dan karyawan. Orang yang memiliki persepsi positif terhadap merokok lebih tidak berisiko berperilaku merokok dibandingkan dengan orang yang memiliki persepsi negatif pada siswa guru dan karyawan di Lembaga Pendidikan Madrasah Mu'allimin Yogyakarta (Hidayati, 2012).

Menurut teori Health Belief Model (HBM) yang merupakan teori perubahan perilaku kesehatan dan model psikologis yang digunakan untuk memprediksi perilaku kesehatan terhadap sesuatu. Perilaku dipengaruhi oleh persepsi dan kepercayaan individu itu sendiri tanpa memandang apakah persepsi dan kepercayaannya sesuai atau tidak sesuai dengan realitas. Berdasarkan persepsi dan kepercayaannya, maka seseorang akan mengambil tindakan atau perilaku yang berhubungan dengan kesehatannya. Variabel demografi sosio psikolog, persepsi kerentanan dan keseriusan, persepsi manfaat dan persepsi hambatan ini dapat mendukung perubahan perilaku individu agar berhenti merokok (Priyoto, 2014).

Proses pembentukan dan atau perubahan perilaku dipengaruhi oleh beberapa faktor yang berasal dari dalam diri individu itu sendiri. Faktor-faktor itu antara lain: susunan saraf pusat, persepsi, motivasi, emosi dan belajar. Susunan saraf pusat memegang peranan penting dalam perilaku manusia karena perilaku merupakan sebuah bentuk perpindahan dari rangsang yang masuk ke rangsang yang dihasilkan. Perpindahan ini dihasilkan oleh susunan saraf pusat dengan unit-unit dasarnya yang disebut neuron. Neuron memindahkan energienergi di dalam impuls-implus saraf. Impuls-impuls saraf indra pendengaran, penglihatan, pembauan, pengecapan dan perubahan disalurkan dari tempat terjadinya rangsangan melalui impulsimpuls saraf ke susunan saraf pusat. 
Perubahan perilaku dalam diri seseorang dapat diketahui melalui persepsi. Persepsi adalah pengalaman yang dihasilkan melalui indra penglihatan, pendengaran, penciuman dan sebagainya. Setiap orang mempunyai persepsi yang berbeda, meskipun objeknya sama. Motivasi diartikan sebagai dorongan untuk bertindak mencapai suatu tujuan tertentu. Hasil dari dorongan dan gerakan inilah yang diwujudkan dalam bentuk perilaku (Notoatmodjo, 2012).

Menurut asumsi peneliti, untuk merubah perilaku responden, dalam hal ini pegawai di Dinas Kesehatan Kota Tebing tinggi agar tidak lagi merokok di kawasan Dinas Kesehatan, maka diperlukan perubahan persepsi dari pegawai tersebut. Harus benar-benar ditanamkan konsep bahwa kawasan tanpa rokok dibuat di Dinas Kesehatan Kota Tebing Tinggi bukan saja bermanfaat untuk pegawai itu sendiri, namun juga berdampak baik bagi orang lain dan lingkungan sekitar, apalagi instansi kesehatan. Akan kelihatan tidak baik sekali apabila di suatu instansi kesehatan ternyata ada pegawainya yang merokok. Padahal tenaga kesehatan merupakan role model yang seharusnya menginspirasi dan memotivasi masyarakat. Dalam hal ini peranan pimpinan sangat penting dalam menjalankan konsep KTR ini sebagaimana mestinya. Penegakan disiplin dan sanksi yang tegas perlu dilaksanakan agar implementasi KTR bisa lebih maksimal.

\section{KESIMPULAN DAN SARAN}

\section{Kesimpulan}

Berdasarkan hasil penelitian dapat disimpulkan bahwa: sebagian besar persepsi pegawai Dinas Kesehatan Kota Tebing Tinggi tentang KTR adalah cukup (60\%), sebagian besar pegawai Dinas Kesehatan Kota Tebing Tinggi adalah merokok $(75,6 \%)$. Ada hubungan yang signifikan antara persepsi tentang KTR dengan perilaku merokok pegawai di Dinas Kesehatan Kota Tebing Tinggi, dengan nilai $\mathrm{p}$ sebesar 0,001 .

\section{Saran}

Disarankan kepada Kepala Dinas Kesehatan Tebing Tinggi agar membentuk satuan petugas (satgas) dan pengelola khusus KTR untuk mengelola dan menertibkan pegawai di Dinas Kesehatan Kota Tebing Tinggi. Sebaiknya informasi yang diberikan mengenai penerapan KTR di Dinas Kesehatan, selain lewat spanduk ataupun stiker larangan merokok, diberikan juga melalui media pengeras suara yang 
tersedia didalam kantor sehingga dapat meningkatkan kesadaran pegawai untuk mengubah perilaku merokoknya.

Kepada Pemerintah Kota Tebing Tinggi disarankan agar meninjau kembali Perwal yang ada dan menambahkan konten pengawasan dan sanksi agar implementasi KTR di daerah Pemerintahan Kota Tebing Tinggi bisa lebih maksimal serta terwujudnya Kota Tebing Tinggi yang besar dari asap rokok.

\section{DAFTAR PUSTAKA}

Aritonang. (2007). Fenomena Wanita Merokok. Yogyakarta: Universitas Gadjah Mada Press.

Binita, A. M. (2016). Hubungan Persepsi Merokok dengan Tipe Perilaku Merokok pada Siswa SMK "X" di Kota Semarang.

Febriani, T. (2014). Pengaruh Persepsi Mahasiswa Terhadap Kawasan Tanpa Rokok (KTR) dan Dukungan penerapannya di Universitas Sumatera Utara.

Hidayat, A. (2014). Metode Penelitian Kesehatan dan Teknik Analisa Data. (Salemba Medika, Ed.). Jakarta.

Hidayati, T. (2012). Persepsi dan Perilaku Merokok Siswa, Guru dan Karyawan Madrasah $\mathrm{Mu} \quad \hat{\mathrm{a}} €^{\mathrm{TM}}$ allimin Muhammadiyah Yogyakarta dan Faktor-faktor yang Berpengaruh.

Kementerian Kesehatan RI, D. (2015). Pedoman Teknis Penegakan Hukum KTR. Jakarta.

Kementerian Kesehatan RI, D. (2016). Petunjuk Teknis Upaya Berhenti Merokok pada Fasilitas Pelayanan Kesehatan Primer (Edisi II).
Jakarta.

Khairi, I. (2014). Persepsi Jajaran Pimpinan tentang Kawasan Tanpa Rokok di Dinas Kesehatan Kabupaten Langkat.

Komasari, D. (2000). Faktor-Faktor Penyebab Merokok pada Remaja.

Kozier, Erb, B. \& S. (2008). Fundamental of Nursing (VII). New Jersey: Prentice Inc.

Medan, P. (2014). Peraturan Daerah Kota Medan No. 3 tentang Kawasan Tanpa Rokok.

Nasution, I. K. (2008). Perilaku merokok pada remaja. Perilaku Merokok Pada Remaja. https://doi.org/10.22216/jen.v2i1.1 372

Notoatmodjo, S. (2012). Teori dan Aplikasi Promosi Kesehatan. (Rineka Cipta, Ed.) (Revisi). Jakarta.

Pemko Tebing Tinggi. (2013). Peraturan Walikota Tebing Tinggi Nomor 3 tentang Kawasan Tanpa Rokok pada Perkantoran, Fasilitas Pelayanan Kesehatan dan Tempat Proses Belajar Mengajar di Lingkungan Pemerintah Kota Tebing Tinggi.

Priyoto. (2014). Teori dan Sikap Perilaku dalam Kesehatan. (N. Medika, Ed.). Yogyakarta.

Rahayuningsih, F. (2015). Hubungan Antara Persepsi Perilaku Merokok dengan Perilaku Merokok Siswa SMK X di Kota Semarang.

Riskesdas. (2013). Perilaku Merokok Masyarakat Indonesia.

Septia, K. (2014). Persepsi Remaja dengan Perilaku Merokok pada Siswa SMA di Bandar Lampung.

Virly, M. (2013). Hubungan Persepsi tentang Bahaya Merokok dengan Perilaku Merokok pada Karyawan di PT Sintas Kurama Perdana Kawasan Industri Pupuk Kujang Cikampek. 